\title{
Prediction of Weld Bead Geometry in Plasma Arc Welding using Factorial Design Approach
}

\author{
${ }^{1 *}$ K. Siva Prasad, ${ }^{2}$ Ch.Srinivasa Rao, ${ }^{2}$ D.Nageswara Rao
}

\author{
${ }^{1}$ Department of Mechanical Engineering, \\ Anil Neeerukonda Institute of Technology \& Sciences, Visakhapatnam, India. \\ ${ }^{2}$ Department of Mechanical Engineering, Andhra University, Visakhapatnam, India \\ *Corresponding Author : kspanits@ gmail.com
}

\begin{abstract}
The effect of various process parameters like welding current, torch height, welding speed and plasma gas flow rate on front melting width, back melting width and weld reinforcement of plasma arc welding on aluminum alloy is investigated by using factorial design approach. Variable polarity plasma arc welding is used for welding aluminum alloy. Trail experiments are conducted and the limits of the input process parameters are decided. Two levels and four input process parameters are chosen and experiments are conducted as per typical design matrix considering full factorial design. Total sixteen experiments are conducted and output responses are measured. The coefficients are calculated by using regression analysis and the mathematical models are constructed. By using the mathematical models the main and interaction effect of various process parameters on weld quality is studied.
\end{abstract}

Key Words: Plasma Arc Welding, Factorial Design, , Regression Analysis, Welding current, Welding speed, Torch height, Plasma gas flow rate, Front Melting Width, Back Melting Width, Weld Reinforcement. 


\section{INTRODUCTION}

The Plasma Arc Welding (PAW) process is essentially an extension of Gas Tungsten Arc Welding (GTAW). The energy density and gas velocity and momentum in the plasma arc are high [1]. As with electron beam and laser beam welding, PAW exhibits a deep-weld effect. Variable Polarity Plasma Arc Welding (VPPAW) is developed for aluminum and its alloy [2]. With VPPAW, $\mathrm{Al}_{2} \mathrm{O}_{3}$ oxide film could be cleaned effectively. Gas in the molten pool could escape fully when vertical welding was applied. Therefore, welding quality of VVPAW is better than ordinary gas shielded welding. Comparing with other arc welding techniques, keyhole variable polarity plasma arc welding, which was developed on the base of industrial manufacturing and experimental research, not only can fulfill cathode cleaning of aluminum alternating current welding, but also decrease largely the burning loss of tungsten electrode. Hence, keyhole plasma arc welding may be the most ideal welding process for middle and thick aluminum alloy plates.

\section{DESCRIPTION}

Aluminum alloy AA5182 of 3mm thick as base material and AA5182 as a filler material are chosen and their chemical compositions are given in Table 1 and Table 2.

Alternating current plasma arc welding is used to weld the base metal [3,4]. Thoriated tungsten electrode of diameter $3 \mathrm{~mm}$ is used and the shielding gas used is argon of flow rate 800 Liters/Hour. The position of the welding gun is vertical to the work piece.

Trail experiments are conducted to establish the values of input variables and their ranges in which experiments have to be conducted. As many factors have the effect on formation of welding seam of aluminum alloy, it is necessary to limit them. Wire feed rate is kept constant at $550 \mathrm{~mm} / \mathrm{min}$

Table 1: Chemical composition of base metal AA5182 (weight percentage)

\begin{tabular}{|l|l|l|l|l|l|l|l|l|l|}
\hline $\mathrm{Si}$ & $\mathrm{Fe}$ & $\mathrm{Cu}$ & $\mathrm{Mn}$ & $\mathrm{Mg}$ & $\mathrm{Cr}$ & $\mathrm{Zn}$ & $\mathrm{Ti}$ & other & $\mathrm{Al}$ \\
\hline 0.06 & 0.19 & 0.02 & 0.24 & 4.46 & 0.03 & 0.03 & 0.01 & 0.02 & Val. \\
\hline
\end{tabular}

Table 2: Chemical composition of filler wire AA5356 (weight percentage)

\begin{tabular}{|l|l|l|l|l|}
\hline $\mathrm{Mg}$ & $\mathrm{Mn}$ & $\mathrm{Cr}$ & $\mathrm{Ti}$ & $\mathrm{Al}$ \\
\hline 5.00 & 0.35 & 0.10 & 0.15 & Val. \\
\hline
\end{tabular}




\section{EXPERIMENTAL PROCEDURE}

The step wise experimental procedure used for this study is briefly explained below.

\subsection{Identification of Input Process Parameters and Response Variables}

Front melting width, back melting width and weld reinforcement are chosen as output parameters and welding current, torch height and welding speed as input process variables. The weld bead parameters are shown in Figure 1.

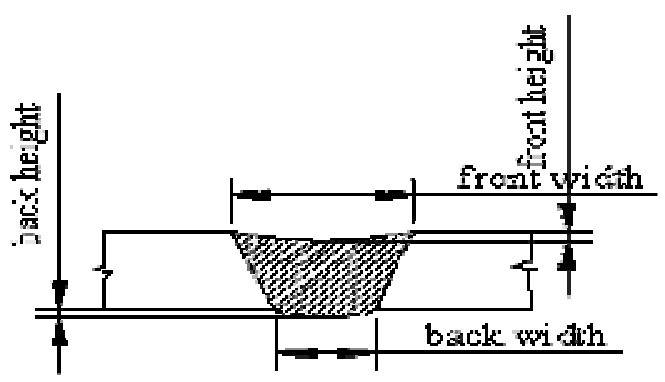

Figure 1: Weld bead parameters

\subsection{Working ranges of input process parameters}

The working ranges of all selected parameters are fixed by conducting trail runs [5]. The experiments are carried out by varying one of the parameters while keeping the rest of them at constant values. The working range of each parameter is decided upon by inspecting the weld bead for a smooth appearance and the absence of visible defects such as surface porosity, undercut etc. The upper limit of the parameter is coded as +1 and the lower limit was coded as -1 . The coded values for intermediate values can be calculated using the following Equation-1:

$\mathrm{X}_{\mathrm{i}}=2\left[2 \mathrm{X}-\left(\mathrm{X}_{\max }+\mathrm{X}_{\min }\right)\right] /\left(\mathrm{X}_{\max }-\mathrm{X}_{\min }\right)$

Where $X_{i}$ is the required coded value of a parameter $X$. The $X$ is any value of the parameter from $X_{\min }$ to $X_{\max }$, where $X_{\min }$ is the lower limit of the parameter and $X_{\max }$ is the upper limit of the parameter. The selected levels of the selected process parameters with their units and notations are given in Table 3. 
Table 3: Chosen welding process parameters and their levels.

\begin{tabular}{|c|c|c|}
\hline Welding parameter & $\begin{array}{c}\text { Min. Value } \\
(-)\end{array}$ & $\begin{array}{c}\text { Max. value } \\
(+)\end{array}$ \\
\hline Welding Current (A), Amperes & 85 & 95 \\
\hline Torch Height(B), mm & 4 & 6 \\
\hline Welding Speed(C), $\mathrm{mm} / \mathrm{sec}$ & 3.75 & 5.42 \\
\hline Plasma gas flow rate (D), $\mathrm{m}^{3} / \mathrm{sec}$ & 0.03 & 0.13 \\
\hline
\end{tabular}

\subsection{Development of Design Matrix}

$2^{\mathrm{k}}$ factorial design matrix for conducting the experiments is selected, where $\mathrm{k}$ is number of input process variables [6]. Two levels and four input process parameters are selected. The number of experiments conducted is $2^{4}=16$. A typical design matrix is shown in Table 4 .

Table 4: Typical design matrix

\begin{tabular}{|l|l|l|l|l|l|l|l|l|l|l|l|l|l|l|l|l|}
\hline & 1 & 2 & 3 & 4 & 5 & 6 & 7 & 8 & 9 & 10 & 11 & 12 & 13 & 14 & 15 & 16 \\
\hline 1 & + & - & - & - & - & + & + & + & + & + & + & - & - & - & - & + \\
\hline 2 & + & + & - & - & - & - & - & - & + & + & + & + & + & + & - & - \\
\hline 3 & + & - & + & - & - & - & + & + & - & - & + & + & + & - & + & - \\
\hline 4 & + & + & + & - & - & + & - & - & - & - & + & - & - & + & + & + \\
\hline 5 & + & - & - & + & - & + & - & + & - & + & - & + & - & + & + & - \\
\hline 6 & + & + & - & + & - & - & + & - & - & + & - & - & + & - & + & + \\
\hline 7 & + & - & + & + & - & - & - & + & + & - & - & - & + & + & - & + \\
\hline 8 & + & + & + & + & - & + & + & - & + & - & - & + & - & - & - & - \\
\hline 9 & + & - & - & - & + & + & + & - & + & - & - & - & + & + & + & - \\
\hline 10 & + & + & - & - & + & - & - & + & + & - & - & + & - & - & + & + \\
\hline 11 & + & - & + & - & + & - & + & - & - & + & - & + & - & + & - & + \\
\hline 12 & + & + & + & - & + & + & - & + & - & + & - & - & - & - & - & - \\
\hline 13 & + & - & - & + & + & + & - & - & - & - & + & + & - & - & - & + \\
\hline 14 & + & + & - & + & + & - & + & + & - & - & + & - & + & + & - & - \\
\hline 15 & + & - & + & + & + & - & - & - & + & + & + & - & - & - & + & - \\
\hline 16 & + & + & + & + & + & + & + & + & + & + & + & + & + & + & + & + \\
\hline
\end{tabular}




\subsection{Recording the Response Variables}

Transverse section of each weld overlay is observed by cutting using power hacksaw from mid length position of the welds and the end faces are machined. These specimens are prepared by the usual metallurgical polishing methods and etched with $2 \%$ nital $[7,8]$. The weld bead profiles are traced using a reflective type optical projector of $10 \mathrm{X}$. The profile images were imported to AutoCAD 2004 software as raster image and profiles are traced in 2D form. From the 2D diagram, the front melting width, back melting width and weld reinforcement are measured. The observed input and output values are shown in Table 5.

Table 5: Experimental input and output values

\begin{tabular}{|c|c|c|c|c|c|c|c|c|c|c|c|}
\hline & A & B & C & D & $\begin{array}{c}\text { Weld } \\
\text { current } \\
(\text { Amps })\end{array}$ & $\begin{array}{c}\text { Torch } \\
\text { height } \\
(\mathrm{mm})\end{array}$ & $\begin{array}{c}\text { Welding } \\
\text { speed } \\
(\mathrm{mm} / \mathrm{sec})\end{array}$ & $\begin{array}{c}\text { Plasma } \\
\text { gas flow } \\
\text { rate }\left(\mathrm{m}^{3} / \mathrm{s}\right)\end{array}$ & $\begin{array}{c}\text { Front } \\
\text { Melting } \\
\text { Width } \\
(\mathrm{mm})\end{array}$ & $\begin{array}{c}\text { Back } \\
\text { Melting } \\
\text { Width } \\
(\mathrm{mm})\end{array}$ & $\begin{array}{c}\text { Weld } \\
\text { Reinforcement } \\
(\mathrm{mm})\end{array}$ \\
\hline 1 & - & - & - & - & 85 & 4 & 3.75 & 0.03 & 6.28 & 0.28 & 3.3 \\
\hline 2 & + & - & - & - & 95 & 4 & 3.75 & 0.03 & 6.2 & 0.82 & 3.04 \\
\hline 3 & - & + & - & - & 85 & 6 & 3.75 & 0.03 & 7.6 & 0.6 & 5.27 \\
\hline 4 & + & + & - & - & 95 & 6 & 3.75 & 0.03 & 7.1 & 0.16 & 4.02 \\
\hline 5 & - & - & + & - & 85 & 4 & 5.42 & 0.03 & 6.05 & 0.73 & 2.52 \\
\hline 6 & + & - & + & - & 95 & 4 & 5.42 & 0.03 & 7.12 & 0.45 & 5.16 \\
\hline 7 & - & + & + & - & 85 & 6 & 5.42 & 0.03 & 6.6 & 0.58 & 3.32 \\
\hline 8 & + & + & + & - & 95 & 6 & 5.42 & 0.03 & 6.48 & 0.47 & 3.3 \\
\hline 9 & - & - & - & + & 85 & 4 & 3.75 & 0.13 & 6.65 & 0.28 & 4.9 \\
\hline 10 & + & - & - & + & 95 & 4 & 3.75 & 0.13 & 6.91 & 0.13 & 5.3 \\
\hline 11 & - & + & - & + & 85 & 6 & 3.75 & 0.13 & 7.6 & 0.06 & 5.27 \\
\hline 12 & + & + & - & + & 95 & 6 & 3.75 & 0.13 & 7.7 & 0.08 & 6.8 \\
\hline 13 & - & - & + & + & 85 & 4 & 5.42 & 0.13 & 6 & 0.69 & 2.95 \\
\hline 14 & + & - & + & + & 95 & 4 & 5.42 & 0.13 & 6.48 & 0.22 & 3.2 \\
\hline 15 & - & + & + & + & 85 & 6 & 5.42 & 0.13 & 7 & 0.26 & 3.9 \\
\hline 16 & + & + & + & + & 95 & 6 & 5.42 & 0.13 & 5.94 & 0.65 & 3 \\
\hline
\end{tabular}

\subsection{Development of Mathematical Models}

The response function representing any of the weld bead parameters can be expressed using Equation 2.

$\mathrm{Y}=\mathrm{f}\left(\mathrm{X}_{1}, \mathrm{X}_{2}, \mathrm{X}_{3}, \mathrm{X}_{4}\right)$

Equation-(2) 
Where $\mathrm{Y}$ is the response i.e. output parameters and $\mathrm{X}_{1}, \mathrm{X}_{2}, \mathrm{X}_{3}, \mathrm{X}_{4}$ are the input variables [9].

The first step is to find suitable approximation for the true function of relationship between $\mathrm{Y}$ and the set of independent variables. Usually, a low-order polynomial in some region of the independent variables is employed. If the response is well modeled by a linear function of the independent variables then the approximating function is the first order model as shown in Equation 3.

\section{$\mathrm{Y}=\mathrm{K}+\mathrm{AX}_{1}+\mathrm{BX}_{2}+\mathrm{CX}_{3}+\mathrm{DX}_{4}+\mathrm{ABX}_{1} \mathrm{X}_{2}+\mathrm{ACX}_{1} \mathrm{X}_{3}+\mathrm{ADX}_{1} \mathrm{X}_{4}+\mathrm{BCX}_{2} \mathrm{X}_{3}+\mathrm{BDX}_{2} \mathrm{X}_{4}+$ $\mathrm{CDX}_{3} \mathrm{X}_{4}+\mathrm{ABCX}_{1} \mathrm{X}_{2} \mathrm{X}_{3}+\mathrm{ABDX}_{1} \mathrm{X}_{2} \mathrm{X}_{4}+\mathrm{ACDX}_{1} \mathrm{X}_{3} \mathrm{X}_{4}+\mathrm{BCDX}_{2} \mathrm{X}_{3} \mathrm{X}_{4}+$ $\mathrm{ABCDX}_{1} \mathrm{X}_{2} \mathrm{X}_{3} \mathrm{X}_{4}$}

Where A, B, C, D are regression coefficeints and $\mathrm{K}$ indicate the noise.

The regression coefficients are calculated using the design matrix shown in Table 4.

The actual mathematical models for Front Melting Width, Back Melting Width and Weld Reinforcement are represented in Equations 4, 5 \& 6 respectively.

Front Melting Width (FMW)

$\mathrm{FMW}=6.7318+0.0093 \mathrm{X}_{1}+0.2706 \mathrm{X}_{2}-0.2731 \mathrm{X}_{3}+0.0531 \mathrm{X}_{4}-0.2068 \mathrm{X}_{1} \mathrm{X}_{2}+0.0368 \mathrm{X}_{1} \mathrm{X}_{3}-$ $0.0743 \mathrm{X}_{1} \mathrm{X}_{4}-0.1868 \mathrm{X}_{2} \mathrm{X}_{3}-0.0331 \mathrm{X}_{2} \mathrm{X}_{4}-0.1193 \mathrm{X}_{3} \mathrm{X}_{4}-0.0968 \mathrm{X}_{1} \mathrm{X}_{2} \mathrm{X}_{3}-0.0431 \mathrm{X}_{1} \mathrm{X}_{2} \mathrm{X}_{4}-$ $0.1168 \mathrm{X}_{1} \mathrm{X}_{3} \mathrm{X}_{4}+0.1018 \mathrm{X}_{2} \mathrm{X}_{3} \mathrm{X}_{4}-0.000625 \mathrm{X}_{1} \mathrm{X}_{2} \mathrm{X}_{3} \mathrm{X}_{4}$

Equation (4)

Back Melting Width (BMW)

$\mathrm{BMW}=0.37+0.0025 \mathrm{X}_{1}-0.08 \mathrm{X}_{2}+0.13625 \mathrm{X}_{3}-0.07375 \mathrm{X}_{4}+0.0475 \mathrm{X}_{1} \mathrm{X}_{2}-0.06125 \mathrm{X}_{1} \mathrm{X}_{3}-$ $0.02875 \mathrm{X}_{1} \mathrm{X}_{4}+0.06375 \mathrm{X}_{2} \mathrm{X}_{3}+0.04625 \mathrm{X}_{2} \mathrm{X}_{4}+0.0225 \mathrm{X}_{3} \mathrm{X}_{4}+0.08125 \mathrm{X}_{1} \mathrm{X}_{2} \mathrm{X}_{3}+$ $0.08125 \mathrm{X}_{1} \mathrm{X}_{2} \mathrm{X}_{4}+0.0675 \mathrm{X}_{1} \mathrm{X}_{3} \mathrm{X}_{4}-0.03 \mathrm{X}_{2} \mathrm{X}_{3} \mathrm{X}_{4}+0.005 \mathrm{X}_{1} \mathrm{X}_{2} \mathrm{X}_{3} \mathrm{X}_{4}$

Equation (5)

Weld Reinforcement (WR) $\mathrm{WR}=4.0781+0.1493 \mathrm{X}_{1}+0.2818 \mathrm{X}_{2}-0.6606 \mathrm{X}_{3}+0.3368 \mathrm{X}_{4}-0.2293 \mathrm{X}_{1} \mathrm{X}_{2}+0.0968 \mathrm{X}_{1} \mathrm{X}_{3}+$ $0.106 \mathrm{X}_{1} \mathrm{X}_{4}-0.3206 \mathrm{X}_{2} \mathrm{X}_{3}+0.0456 \mathrm{X}_{2} \mathrm{X}_{4}-0.4931 \mathrm{X}_{3} \mathrm{X}_{4}-0.2468 \mathrm{X}_{1} \mathrm{X}_{2} \mathrm{X}_{3}+0.2268 \mathrm{X}_{1} \mathrm{X}_{2} \mathrm{X}_{4}$ $0.4193 \mathrm{X}_{1} \mathrm{X}_{3} \mathrm{X}_{4}+0.1806 \mathrm{X}_{2} \mathrm{X}_{3} \mathrm{X}_{4}-0.0381 \mathrm{X}_{1} \mathrm{X}_{2} \mathrm{X}_{3} \mathrm{X}_{4}$

Equation (6)

\section{RESULTS \& DISCUSSION}

Graphs 2, 3, 4 represents the scatter diagram indicated how the experimental values and predicted values (Non-linear model values) vary. Variation of Front melting width, Back melting width and weld reinforcement with welding current, Torch height, welding speed, Plasma gas flow rate are shown in graphs 5,6,7,8. Comparisons of experimental and predicted values are shown in Table 6. 
Table 6: Comparison of experimental and predicted values

\begin{tabular}{|c|c|c|c|c|c|}
\hline \multicolumn{2}{|c|}{ Front Melting Width(mm) } & \multicolumn{2}{c|}{ Back Melting Width $(\mathrm{mm})$} & \multicolumn{2}{c|}{ Weld Reinforcement $(\mathrm{mm})$} \\
\hline $\begin{array}{c}\text { Experimental } \\
\text { value }\end{array}$ & $\begin{array}{c}\text { Predicted } \\
\text { value }\end{array}$ & $\begin{array}{c}\text { Experimental } \\
\text { value }\end{array}$ & $\begin{array}{c}\text { Predicted } \\
\text { value }\end{array}$ & $\begin{array}{c}\text { Experimental } \\
\text { value }\end{array}$ & $\begin{array}{c}\text { Predicted } \\
\text { value }\end{array}$ \\
\hline 6.28 & 6.575298 & 0.28 & 0.375313 & 3.3 & 3.855756 \\
\hline 6.2 & 6.642652 & 0.82 & 0.455938 & 3.04 & 3.913244 \\
\hline 7.6 & 7.049802 & 0.6 & 0.249063 & 5.27 & 4.434619 \\
\hline 7.1 & 6.980148 & 0.16 & 0.297188 & 4.02 & 4.263281 \\
\hline 6.05 & 6.408977 & 0.73 & 0.528125 & 2.52 & 3.436994 \\
\hline 7.12 & 6.619773 & 0.45 & 0.474375 & 5.16 & 3.914806 \\
\hline 6.6 & 6.694023 & 0.58 & 0.44125 & 3.32 & 3.718831 \\
\hline 6.48 & 6.671327 & 0.47 & 0.43375 & 3.3 & 3.740069 \\
\hline 6.65 & 6.727302 & 0.28 & 0.310625 & 4.9 & 4.365094 \\
\hline 6.91 & 6.800148 & 0.13 & 0.289375 & 5.3 & 4.615306 \\
\hline 7.6 & 7.139198 & 0.06 & 0.20625 & 5.27 & 4.776331 \\
\hline 7.7 & 7.032252 & 0.08 & 0.23125 & 6.8 & 5.043569 \\
\hline 6 & 6.449023 & 0.69 & 0.468438 & 2.95 & 3.563056 \\
\hline 6.48 & 6.548827 & 0.22 & 0.377813 & 3.2 & 3.833344 \\
\hline 7 & 6.773577 & 0.26 & 0.370938 & 3.9 & 3.876919 \\
\hline 5.94 & 6.596473 & 0.65 & 0.410313 & 3 & 3.898381 \\
\hline
\end{tabular}

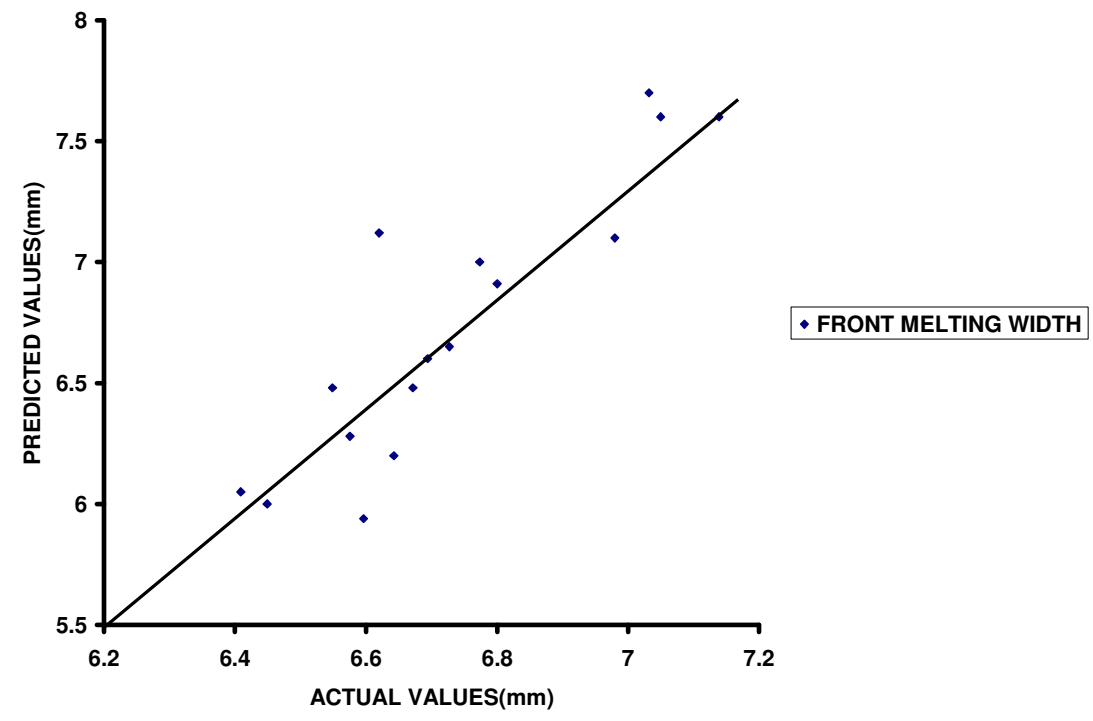

Figure 2: Scatter plot for Front melting width 


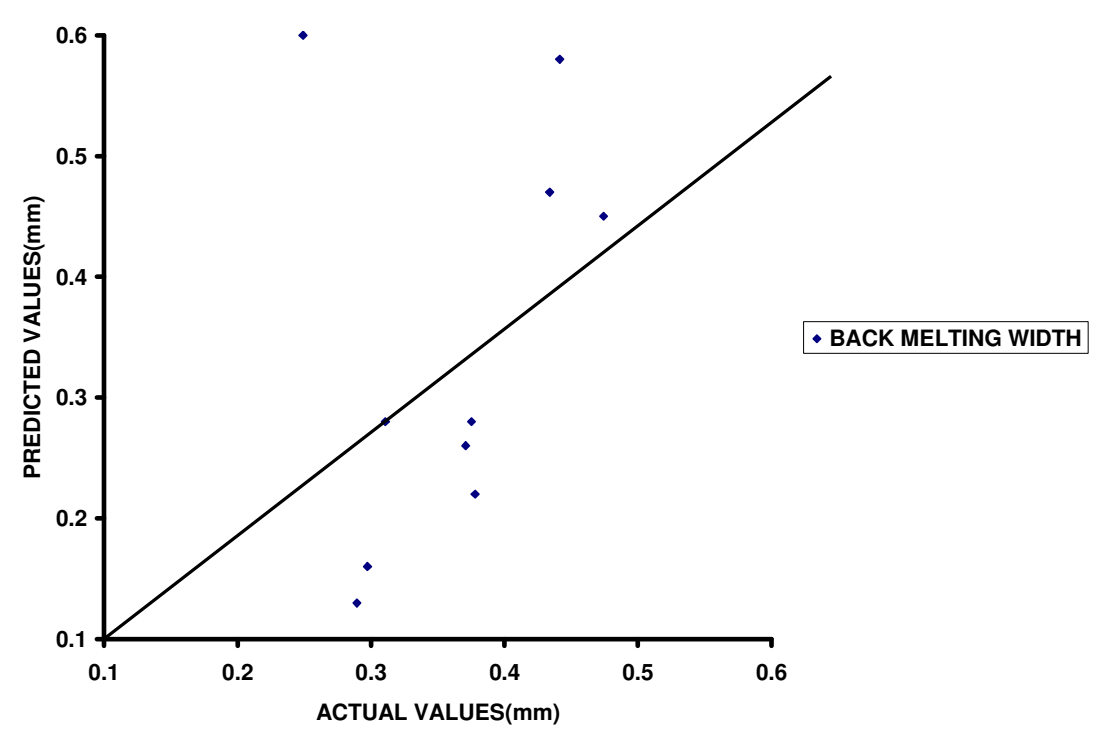

Figure 3: Scatter plot for Back melting width

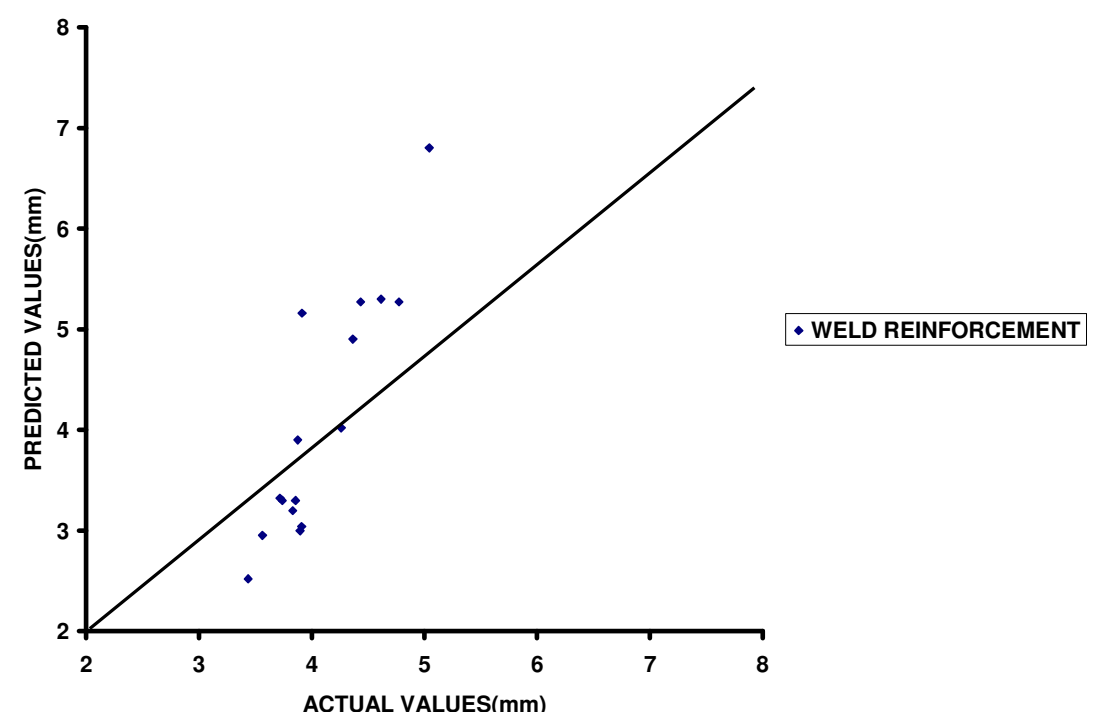

Figure 4: Scatter plot for Weld Reinforcement 


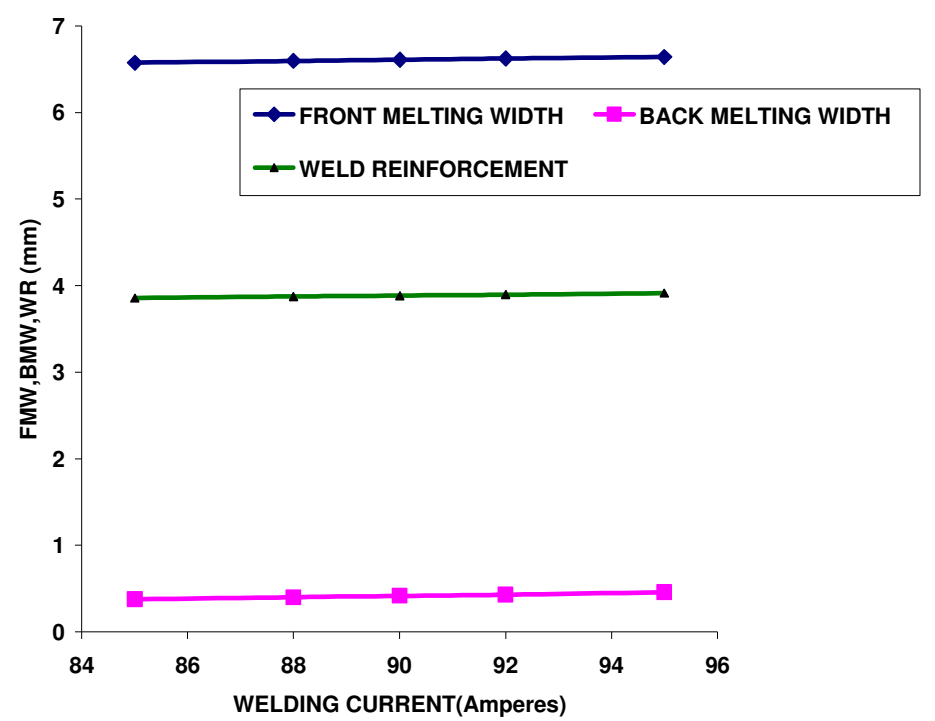

Figure 5: Variation of FMW, BMW, WR with Welding current

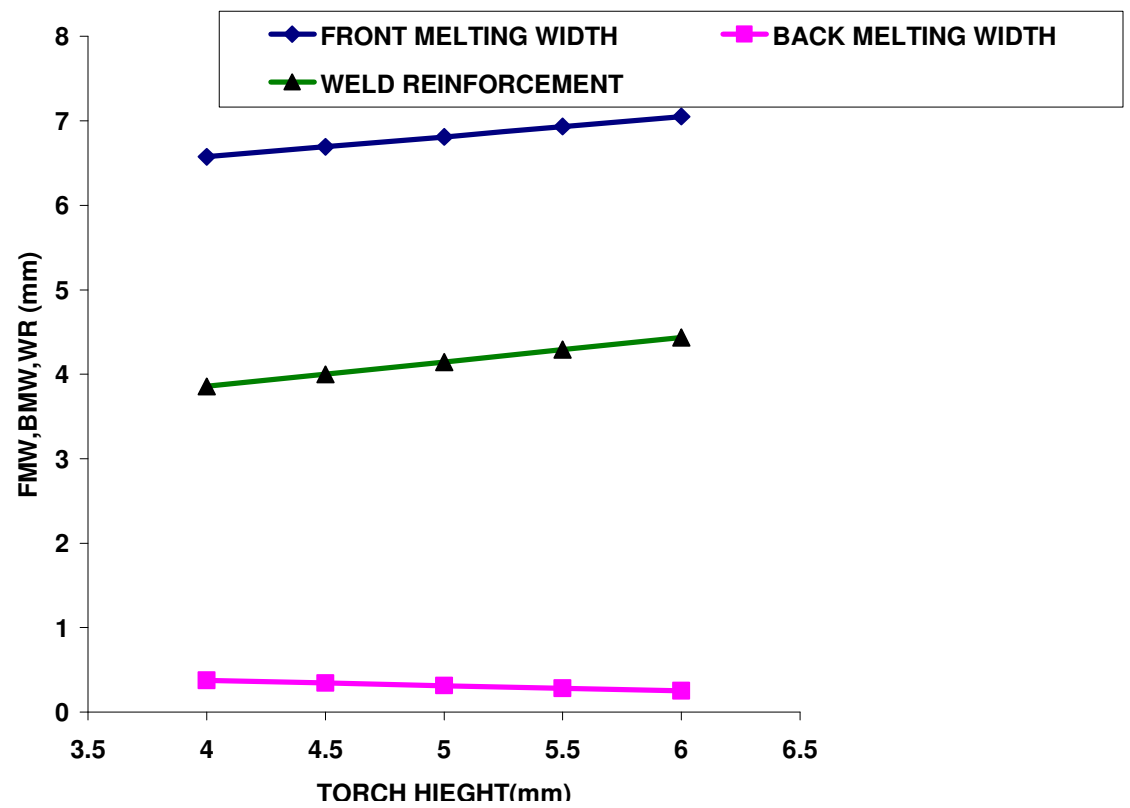

Figure 6: Variation of FMW, BMW, WR with Torch Height 


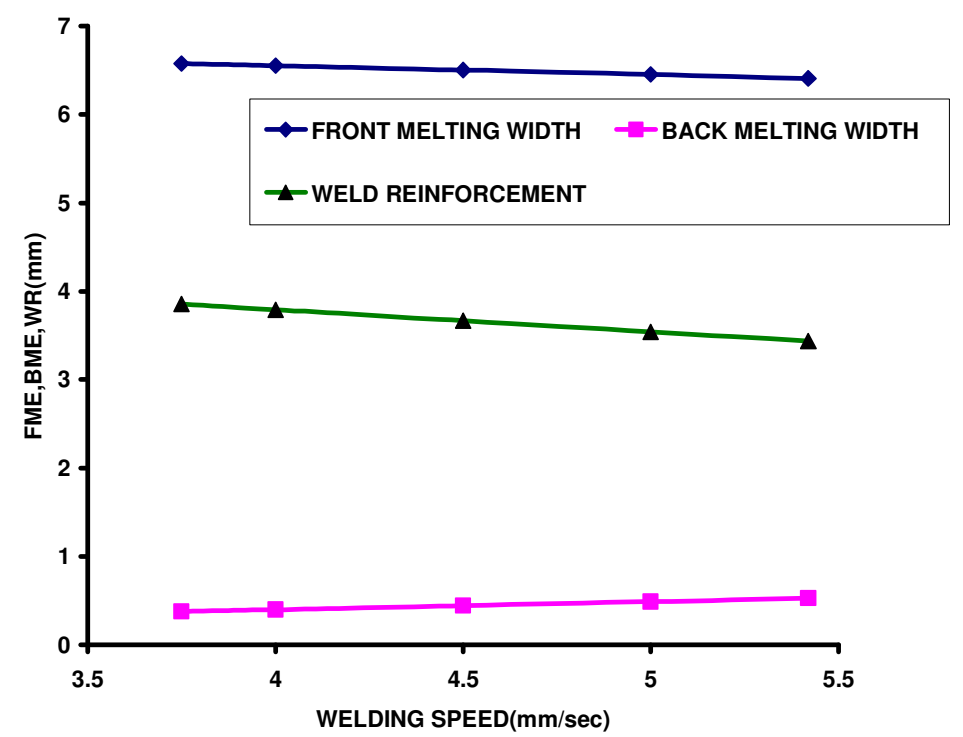

Figure 7: Variation of FMW, BMW, WR with Welding Speed

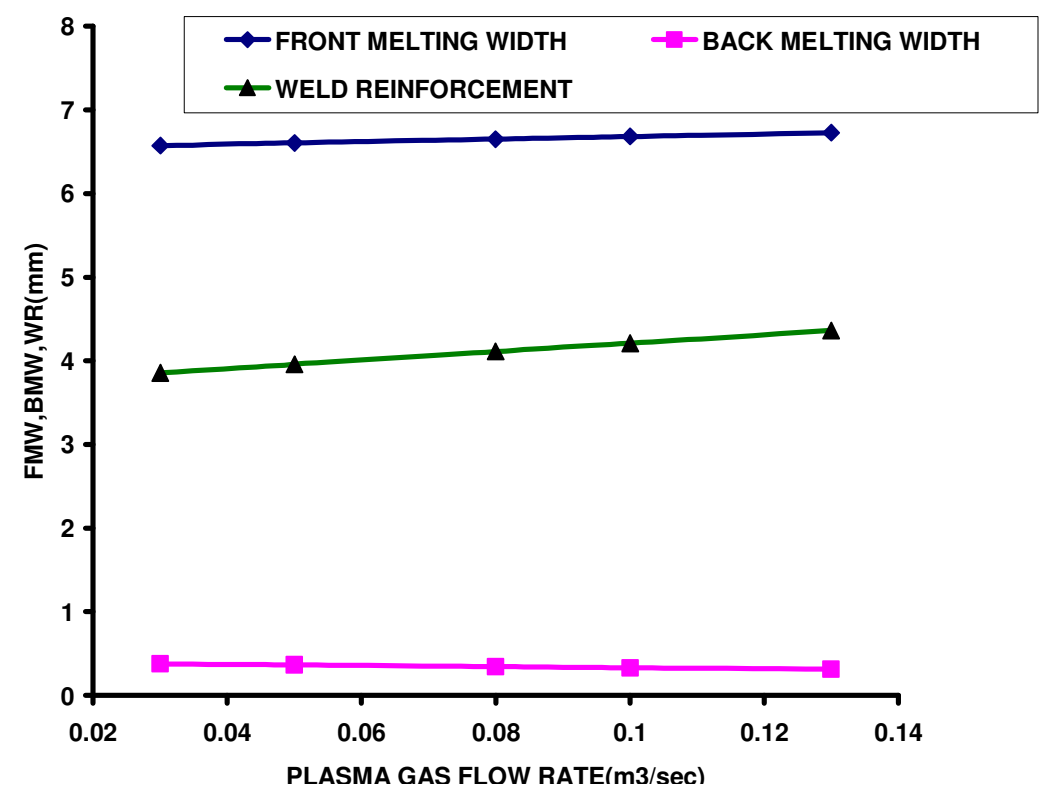

Figure 8: Variation of FMW, BMW, WR with Plasma gas flow rate 


\section{CONCLUSIONS}

From the experimentation results and developed mathematical models the following observations are made.

1. The experimental and predicted values are well with in the limits; however there is some variation in the experimental and predicted values because we had considered only four input process parameters and two levels in the present paper. The accuracy of the predicted values can be improved by considering more input process parameters and more levels.

2. By keeping Torch height and welding speed, Plasma gas flow rate constant and increasing welding current, Front melting width, Back melting width and weld reinforcement decreases.

3. By keeping welding current, welding speed, plasma gas flow rate constant and increasing Torch height, Front melting width and Weld Reinforcement increases where as Back Melting width decreases.

4. By keeping welding current, Torch height, plasma gas flow rate constant and increasing welding speed, Front melting width and Weld Reinforcement decreases where as Back Melting width increases.

5. By keeping welding current, Torch height, welding speed constant and increasing plasma gas flow rate, Front melting width and Weld Reinforcement decreases where as Back melting width increases.

6. Because of the complexity in the input parameters the present work is limited to four parameters variation and its influence on Front melting width, Back melting width and Weld reinforcement. However there are other factors like wire feed rate, flow rate of shielding gas etc which also influence the weld quality are kept constant.

7. In the present paper we had taken only factors and two levels of the input variables; however for better results more input process parameters and more levels should be condidered.

\section{ACKNOWLEDGEMETS}

We extend our sincere thanks to Shri. R.Gopala Krishna, Director (Technical), M/s Metallic Bellows (I) Pvt Ltd, Chennai, India for his support in carrying out the experimentation work . We also thank all the people who helped us in preparing this paper.

\section{REFERENCES}

[1] Howard Cary. B, 1979, Modern Welding Technology, Prentice Hall Inc, Englewood Cliffs, NJ.

[2] H.X.Wang, Y.H.Wei, C.L.Yang, 2007, Numerical simulation of variable polarity vertical-up plasma arc welding, J. Computational Materials Science, 38,pp.571587. 
[3] Roberts DK, Wells AA, 1954, Fusion welding of aluminum alloys Br, Weld J, 12: pp.553-559.

[4] ASM Handbook, 1993, welding, brazing and soldering, vol.6.ASM, USA.

[5] V.K.Guptha, R.S.Parmar, 1989, Fractional factorial technique to predict dimensions of the weld bead in automatic submerged arc welding, J. Inst.Eng. (India), pp.67-70.

[6] G. Cohran, M. Cox, 1963, Experimental Designs, Asia Publishing House, India.

[7] Nouri M, Abdollah-zadehy A, Malek F, 2007, Effect of welding parameters on dilution and weld bead geometry in cladding. J Mater Sci Technol, 23(6), pp. 817-822.

[8] J.P.Ganjigatti, D.K.Prathhar, A.Roy Choudary, 2008,Modeling of the MIG welding Process using stastical approaches IntJ Adv Manuf Technol, 35, pp. 1166-1190.

[9] Montgomery dc, 1997, Design and analysis of Experiments, 4th edition, Wiley, NewYork. 